\title{
D-optimal Design Application to Study Enhanced Biostimulation of Used Motor Oil Contaminated Soil
}

\author{
Kabir Abogunde Abdulyekeen ${ }^{1}$, Abdulhaqq Ameen Ibrahim ${ }^{1}$, Abdulkadir Aliyu ${ }^{1}$, \\ Abubakar Salis ${ }^{1}$, Mahiru Datti Magaji ${ }^{1}$, Lydia Oluwafunsho ljaola ${ }^{1}$
}

\author{
${ }^{1}$ Abubakar Tafawa Balewa University \\ Tawafa Belewa Way, P. M. B. 0248, Bauchi, 740272, Nigeria
}

DOI: $10.22178 /$ pos.46-5

LCC Subject Category: TD878-894

Received 20.04.2019

Accepted 27.05.2019

Published online 31.05.2019

Corresponding Author: Kabir Abogunde Abdulyekeen ayekeenkabir@atbu.edu.ng
(C) 2019 The Authors. This article is licensed under a Creative Commons Attribution 4.0 License (c) (1)
Abstract. The indiscriminate disposal of fresh and used motor oil into the environment (land and water) is a common practice in Nigeria and this practice has contributed to its soil contamination and makes up a greater percentage of polluted ground in the world. Over the years, the contamination of auto-mechanic workshops by used oil and fresh oil has been left uncared for, Soil contaminated with fresh and used motor oil creates a serious effect on plant tissues, soil components, and its microorganisms, human and other animal health. Optimization of a biostimulation process used in the treatment of used motor oil contaminated soil has been carried out. D-optimal design of response surface methodology with one numerical factor and a categorical factor at two levels was employed to generate 10 experimental runs for the biostimulation system. The input variables of the system were palm bunch ash (a stimulant) and pollution level. The two levels of the latter factor considered were $5 \%$ and $10 \%(\mathrm{w} / \mathrm{w})$ pollution level, while the response of the system was oil and grease $(O \& G)$ removal. The biostimulation experiments were carried out according to the RSM design, and the experimental data obtained were analyzed using the quadratic model. The results of the analyses showed that the developed quadratic model was able to represent the system with both input factors affecting the system significantly since $p$-values for the model was found to be less than 0.05 . The results also showed that $0 \& G$ removal was affected by both the PBA and the pollution level. It was also observed from the numerical optimisation carried out that $100 \%$ and $83.36 \%$ O\&G removal was attained at $5 \%$ and $10 \%$ pollution level respectively after ten weeks of the study. The findings of this work revealed that palm bunch ash (PBA) can be used as a stimulant for the bioremediation of used motor oil contaminated soil. Thus, its application in the treatment of oil-contaminated soil is highly recommended.

Keywords: palm bunch ash; used motor oil; D-optimal design; biostimulation; RSM; categorical factor; pollution level.

\section{INTRODUCTION}

Used motor oil is a mixture of substances such as chlorinated biphenyls, chlorodibenzofurans, heavy metals, petroleum hydrocarbons, lubricative additives, decomposition products [1, 2, 3, 4]. It is produced when fresh engine oil is subjected to high temperature, high mechanical strain and high pressure $[1,2,4]$. The indiscriminate disposal of fresh and used motor oil into the environment (land and water) is a common practice in Nigeria and this practice has contributed to its soil contamination and makes up a greater percentage of polluted ground in the world $[1,4,5]$. In the developing countries with poor regulatory policies on the environment, the problem is very severe $[5,6,7,9]$.
Over the years, the contamination of automechanic workshops by used oil and fresh oil has been left uncared for, and continuous accumulation of the oil is of high health and environmental concern as a result of the hazards associated with it [1]. Soil contaminated with fresh and used motor oil create a serious effect on plant tissues, soil components, and its microorganisms, human and other animal health $[1,5,8]$.

Among the methods used for remediation of oilcontaminated soil, biological methods are more economical and efficient than chemical and physical ones [23]. The later methods, such as dispersion, dilution, sorption, volatilization, abiotic transformations though important, have their limitations. These limitations include; ex- 
pensive to be applied at a large scale, toxic to the environment, and it involves the use of sophisticated technology [1].

Bioremediation is the process of degrading pollutants in the environment by autochthonous or allochthonous microorganisms such as bacteria and fungi or plants to damage, destabilize, or detoxify hazardous substances in soil or render them harmless by using them as their carbon and energy source $[8,10]$.

One of the essential requirements for oil spill bioremediation is the presence of microorganisms with appropriate metabolic capabilities [26, 16]. One of the widely used bioremediation procedure is biostimulation of the indigenous microorganisms by applying nutrients, as input of large quantities of contaminants (i.e., carbon sources) tends to result in quick depletion of the available pools of major inorganic nutrients, such as $\mathrm{N}$ and $\mathrm{P}[11,18]$. Biostimulation has been achieved by adding an animal and plant waste as well as inorganic fertilizer as biostimulants $[14,15,16]$. The use of the former is encouraged as it does not only reduce environmental pollution but also serves as a way of converting waste to wealth [15]. The biowaste improves the bioremediation process by adding essential nutrients such as nitrogen, potassium and phosphorus to the soil which increase the fertility of the soil as well as the growth of the microbes. Bioremediation is a multifactor dependent system. Thus, its optimization is of great importance [15].

Conventionally, the efficiency of a multivariable dependent process is studied by varying one factor at a time while other factors are kept constant. This method normally ignores the interactions occurring among the factors. Thus, it may not give the best conditions that give the optimum efficiency of the process under investigation [15]. Consequently, Response Surface Methodology (RSM) has been discovered as an effective statistical method of optimizing a process using designs such as Central Composite Design (CCD), Box-Behnken design and D-optimal design. Response Surface Methodology, apart from revealing the true optimum conditions with a minimal number of experiments compared to the conventional method, gives the mathematical model(s) defining the relationships between the response(s) and the factors [14].

In the recent years, RSM has been successfully used to optimize many processes including bioremediation system $[13,17,19,20,21,22]$. How- ever, the reported researches on statistical optimization of biostimulation are few compared to the conventional types. Even, the majority of the reported optimization works are on the use of nutrient quantity as a numeric factor, only few could be found on the use of biostimulants type as a categorical factor, and none could be found on the use of pollution level as a categorical factor.

Therefore, in this research work, the D-optimal design of RSM has been used to investigate the effect of numeric and categorical factors on the bioremediation of soil artificially contaminated with used motor oil. The variables of the system were biostimulant (palm bunch ash) and pollution level that was of two categories, namely, lower level (5\%), and higher level (10\%). The response was the oil and grease percentage removal.

\section{MATERIALS AND METHOD}

Samples Collection. An Un-impacted surface soil (0-15 cm) was collected from Abubakar Tafawa Balewa University, Yelwa Campus Bauchi, Bauchi State - Nigeria in a black polythene bag and kept in the university Chemical Engineering Reaction Laboratory. The soil is homogenised and sieved with $2 \mathrm{~mm}$ pore size sieve. The used motor oil (UMO) was obtained from the old Dan Gombe Auto-Mechanic Workshop located in Bauchi, Nigeria. Palm bunch ash (PBA) was obtained from Bayelsa (Sagbama L.G.A, Nigeria) and transported to Abubakar Tafawa Balewa University Bauchi, Bauchi State - Nigeria.

Samples Characterization. The analyses carried out on the soil, and the PBA included the moisture content, $\mathrm{pH}$, organic carbon, the phosphorus and nitrogen contents. The method adapted for each of the analyses is given in Table 1

Bioremediation Experiment. In order to optimise the range of experimentation for one numerical and two-level categorical factors D-optimal design, the following experiments were performed in plastic containers (used as bioreactors) kept at room temperature. Soil samples (1000 g) were placed in treatment cells (plastic containers), and they were artificially polluted with UMO to two pollution levels ( $5 \%$ and $10 \% \mathrm{w} / \mathrm{w}$ ). The UMOpolluted soil in each treatment cell was amended with different amount of PBA (50 to $150 \mathrm{~g}$ ). 
Table 1 - Methods used for Determination of Physicochemical Properties

\begin{tabular}{|l|l|c|}
\hline \multicolumn{1}{|c|}{ Parameter } & \multicolumn{1}{|c|}{ Method } & Source \\
\hline $\mathrm{pH}$ & $\begin{array}{l}\text { Moisture adjustment in } \\
1: 1 \text { (weight of soil to the } \\
\text { volume of water) followed } \\
\text { by agitation of the mixture } \\
\text { before pH Measurement }\end{array}$ & {$[18]$} \\
\hline $\begin{array}{l}\text { Moisture } \\
\text { content }\end{array}$ & $\begin{array}{l}\text { Drying method based on } \\
\text { moisture loss per dry } \\
\text { weight }\end{array}$ & {$[13]$} \\
\hline $\begin{array}{l}\text { Phosphorous } \\
\text { content }\end{array}$ & Spectrophotometry & {$[1]$} \\
\hline $\begin{array}{l}\text { Nitrogen } \\
\text { content }\end{array}$ & Kjedahl method & {$[1]$} \\
\hline $\begin{array}{l}\text { Total organic } \\
\text { carbon }\end{array}$ & Titrimetric method & {$[25]$} \\
\hline
\end{tabular}

The soil in the treatment cells used as controls is not amended with PBA. Table 2 gives the level of the independent variables while the experimental design matrix is given in Table 3.

Table 2 - Level of the numerical and categorical factors chosen for the experimental design

\begin{tabular}{|l|c|c|}
\hline Numerical factor & Lower level & Higher level \\
\hline PBA (g) & 50 & 150 \\
\hline Categorical factor & 1st level & 2nd level \\
\hline UMO pollution, $\%$ & 5 & 10 \\
\hline
\end{tabular}

Table 3 - Summary of the Experimental Design Matrix

\begin{tabular}{|c|c|c|c|c|c|}
\hline \multirow[t]{2}{*}{ Run } & \multicolumn{2}{|c|}{$\begin{array}{c}\text { Factor } 1- \\
\text { PBA }\end{array}$} & \multicolumn{2}{|c|}{$\begin{array}{c}\text { Factor } 2- \\
\text { Pollution Level } \\
\%(w / w)\end{array}$} & \multirow{2}{*}{$\begin{array}{c}\text { Responses } \\
\begin{array}{c}\text { O\&G } \\
\text { (ppm) }\end{array}\end{array}$} \\
\hline & Coded & Actual & Coded & Actual & \\
\hline 1 & 1.0 & 150 & 1 & 10 & \\
\hline 2 & 1.0 & 150 & -1 & 5 & \\
\hline 3 & 0.0 & 100 & 1 & 10 & \\
\hline 4 & -0.5 & 75 & 1 & 10 & \\
\hline 5 & -1.0 & 50 & -1 & 5 & \\
\hline 6 & 1.0 & 150 & 1 & 10 & \\
\hline 7 & 0.0 & 100 & -1 & 5 & \\
\hline 8 & 0.5 & 125 & -1 & 5 & \\
\hline 9 & -1.0 & 50 & -1 & 5 & \\
\hline 10 & -1.0 & 50 & 1 & 10 & \\
\hline $\begin{array}{l}11 \\
\text { (Control) }\end{array}$ & - & - & - & 5 & \\
\hline $\begin{array}{l}12 \\
\text { (control) }\end{array}$ & - & - & - & 10 & \\
\hline
\end{tabular}

The experimental response is the percentage oil \& grease removal which was calculated using Equation 1.

$$
O \& G(\%)=\frac{s_{i}-s_{t}}{s_{i}} \times 100
$$

where $S_{i}$ - initial concentration of O\&G in ppm, $S_{t}$ - concentration of $O \& G$ in ppm at a particular bioremediation time.

The contents of the treatment cells were pulverised three times a week for aeration and kept moist during the ten weeks experimental period. Samples were withdrawn at a two-week interval for residual oil \& grease. The statistical software Design Expert 7.0.0. was used for the analysis of variation (at 95\% confidence level) to determine the significance of each term in the fitted equation and to estimate the goodness of fit in each case.

Determination of oil \& grease content of the soil. The gravimetric method was used to determine the oil and grease content as described by [11]. $5.0 \mathrm{~g}$ of the UMO polluted soil was weighed and transferred in to test tube after which $5.0 \mathrm{ml}$ of nhexane was added, and the mixture was shaken vigorously for 5.0 minutes. The mixture was allowed to settle and was decanted into a $50 \mathrm{ml}$ beaker whose weight determined as $\mathrm{w}_{1}$ in $\mathrm{g}$. The procedure was repeated three times to bring the total solvent to $20 \mathrm{ml}$; the mixture was left open in the laboratory for 24 hours for the n-hexane to evaporates completely. The weight of the beaker after evaporation was weighed as $\mathrm{w}_{2}$ in $\mathrm{g}$. The oil and grease content was calculated using Equation 2.

$$
\begin{aligned}
& O \& G(p p m)= \\
& =\frac{w_{2}-w_{1}}{\text { weight of soil sample taken }} \times 10^{6}
\end{aligned}
$$

Statistical Experimental Design, Analysis and Optimization. D-optimal design of response surface methodology (RSM) was used to generate a total of 10 experimental runs by using stimulant (PBA - 50 to $150 \mathrm{~g}$ ) as the numerical factor and pollution level ( $5 \%$ and $10 \%$ ) as the categorical factor.

After each experimental run has been carried out, the responses were analysed using the quadratic model. A numerical method was used to 
perform the optimisation of the biochemical system. In the optimisation criteria, the goals of the two factors considered were set to be in range while those of the responses were maximised.

Determination of total bacterial count. The enumeration of the total bacterial count present in the treatment cells was determined by the spread plate techniques. The sample from each of the treatment cells was subjected to serial dilution which was plated on nutrient agar (NA) oxoid and incubated at $28 \pm 2{ }^{\circ} \mathrm{C}$ for 24 hour and plate that yields count between 30-300 colonies were counted [9].

\section{RESULTS AND DISCUSSION}

Physicochemical properties of the samples. The key parameters in the biochemical system are the $\mathrm{pH}$ and the nutrients such as nitrogen and phosphorous. The $\mathrm{pH}$ of the UMO polluted soil was measured to be 6.6 and 6.9 for $5 \%$ and $10 \%$ pollution level respectively, while that of PBA was 12.3. The nitrogen, organic carbon and phosphorus contents of the UMO polluted soil were determined to be $2.5 \mathrm{ppm}, 13.5 \%$ and $1156.6 \mathrm{ppm}$ for the $10 \%$ pollution level and $1.0 \mathrm{ppm}, 7.8 \%$ and $1135.14 \mathrm{ppm}$ for the $5 \%$ pollution level. Also, the respective value of these parameters measured for PBA were $3.7 \mathrm{ppm}$, $12 \%, 2551.35 \mathrm{ppm}$. The oil and grease concentration of the UMO polluted soil was measured to be $50000 \mathrm{ppm}$ and $100000 \mathrm{ppm}$ for $5 \%$ and $10 \%$ pollution level respectively.

All the $\mathrm{pH}$ values were within an acceptable range of 5.5-8.5 for an effective biochemical process [24]. It was evident that the selected biostimulants were rich in phosphorus which is one of the nutrients required for effective bioremediation. The oil and grease value of the UMO polluted soil was found to be above the minimum permissible concentration of $500 \mathrm{ppm}$ set by $\mathrm{Ni}-$ geria Ministry of Environment as reported by [2], hence the need for remediation of the soil.

Experimental design and analysis of variance results. The responses of the D-optimal design of RSM with 2 - level categorical factor designed for this work is given in Table 4 .

Table 4 - Summary of the Experimental Design Matrix

\begin{tabular}{|l|c|c|c|c|c|}
\hline \multirow{2}{*}{ Run } & \multicolumn{2}{|c|}{$\begin{array}{c}\text { Factor 1 - } \\
\text { PBA }\end{array}$} & $\begin{array}{c}\text { Factor 2 - Pol- } \\
\text { lution Level \% } \\
(\mathrm{w} / \mathrm{w})\end{array}$ & Responses \\
\cline { 2 - 6 } & Coded & Actual & Coded & Actual & $\begin{array}{c}\text { O\&G } \\
\text { (ppm) }\end{array}$ \\
\hline 1 & 1.0 & 150 & 1 & 10 & 86.5 \\
\hline 2 & 1.0 & 150 & -1 & 5 & 100 \\
\hline 3 & 0.0 & 100 & 1 & 10 & 79.2 \\
\hline 4 & -0.5 & 75 & 1 & 10 & 74.5 \\
\hline 5 & -1.0 & 50 & -1 & 5 & 95.5 \\
\hline 6 & 1.0 & 150 & 1 & 10 & 79.2 \\
\hline 7 & 0.0 & 100 & -1 & 5 & 100 \\
\hline 8 & 0.5 & 125 & -1 & 5 & 99.4 \\
\hline 9 & -1.0 & 50 & -1 & 5 & 99 \\
\hline 10 & -1.0 & 50 & 1 & 10 & 63 \\
\hline $\begin{array}{l}11 \text { (Con- } \\
\text { trol) }\end{array}$ & - & - & - & 5 & 88 \\
\hline $\begin{array}{l}12 \text { (con- } \\
\text { trol) }\end{array}$ & - & - & - & 10 & 58 \\
\hline
\end{tabular}

The results of the analysis of variance obtained when the quadratic model was used for the analysis of the experimental data are given in Table 5.

Table 5 - ANOVA for O\&G Removal Quadratic Model

\begin{tabular}{|l|c|c|c|c|c|}
\hline Source & Sum of squared & Difference (Df) & Mean square & F value & p-value \\
\hline Model & 1508.27 & 4 & 377.07 & 37.74 & $<0.0006$ \\
\hline A-PBA & 158.01 & 1 & 158.01 & 15.82 & $<0.0106$ \\
\hline B-Pollution level & 1335.63 & 1 & 1335.63 & 133.69 & 0.0001 \\
\hline AB & 102.55 & 1 & 102.55 & 10.26 & 0.0239 \\
\hline A^2 & 27.09 & 1 & 27.09 & 2.71 & $<0.1606$ \\
\hline Residual & 49.95 & 5 & 9.99 & & \\
\hline Lack of fit & 17.18 & 3 & 5.73 & 0.35 & 0.7982 \\
\hline Pure error & 32.77 & 2 & 16.38 & & \\
\hline Cor Total & 1558.22 & 9 & & & \\
\hline Std.Dev. & 3.16 & R-Squared & 0.9679 & & \\
\hline Mean & 56.51 & Adj R-Squared & 0.9423 & & \\
\hline C.V. $\%$ & 3.61 & Pred R-Squared & 0.8335 & & \\
\hline PRESS & 259.51 & Adeq Precision & 16.313 & & \\
\hline
\end{tabular}


The quadratic model is presented in Equations 3 and 4 for O\&G removal at $5 \%$ and $10 \%$ pollution level respectively.

$O \& G(5 \%)=+84.02444+$ $0.33333 * P B A-1.59160 E-$ $-003 * P B A^{2}$
$O \& G(10 \%)=+43.85763+$

$+0.50206 * P B A-1.59160 E-$

$-003 * P B A^{2}$

It was obvious that the biostimulant and the pollution level affected the responses. The 0\&G removal increased with increase in PBA addition for the two pollution level. However maximum O\&G removal was achieved at 5\% pollution level $(100 \%)$. This trend is evident in Figure 1.
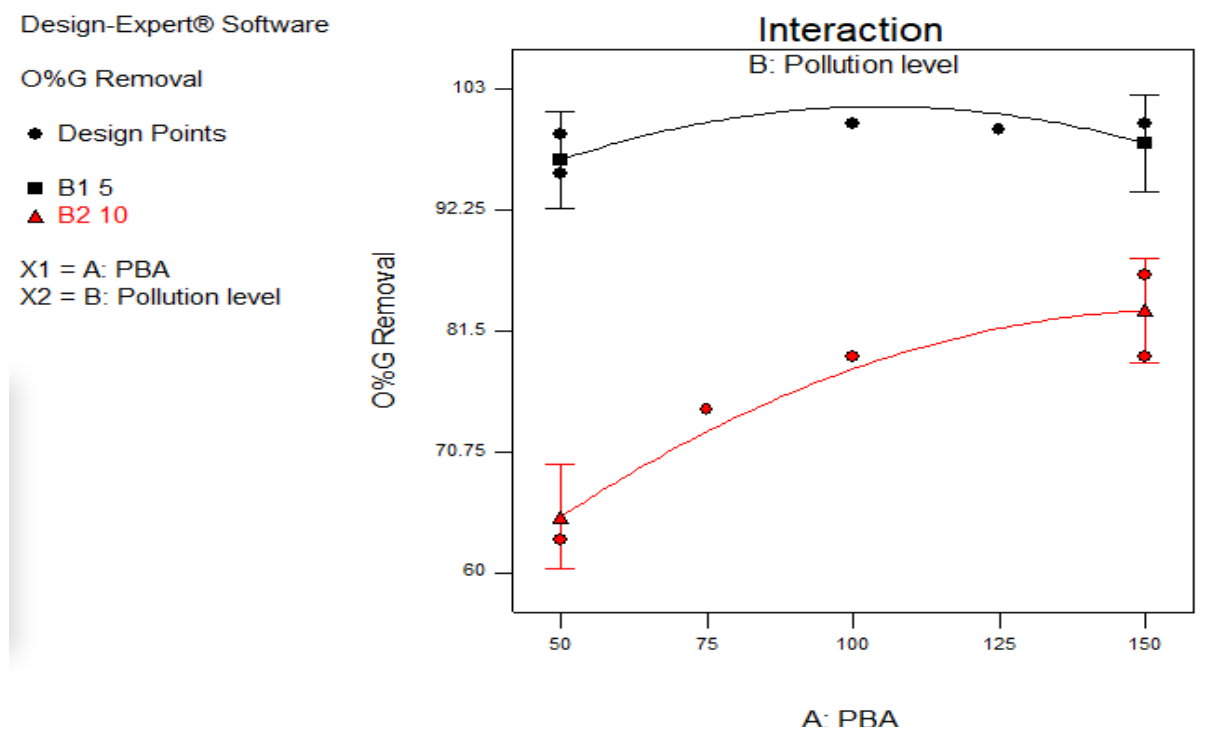

Figure 1 - The effect of PBA and pollution level on oil and grease removal

A similar result was obtained in the work of [5]. This maximum 0\&G removal may be because the PBA is richer in nutrients (nitrogen and phosphorus) which are important nutrients for microbial degradation of organic pollutants [21, 12]. The improved $0 \& G$ removal can be associated to the fact that one of the nutrients needed for organism growth is phosphorus, this means that when it is present in high concentration, the growth rate is expected to be favoured. As shown in Table 4, the quadratic model was found to be significant for $0 \& G$ removal as evident in the probability of error value ( $\mathrm{p}$-value) of less than 0.001 on $95 \%$ confidence level. Also, all the model terms (A-PBA, B-pollution level, ABinteraction of PBA and pollution level) were found to affect the response that is significant as evident in the p-values of the terms being less 0.05 except the square of the of PBA whose pvalue is greater than 0.05 . The R-squared of the model was close to 1 , and the Pred R-squared is in good agreement with the Adj R-squared. The high R-squared value can be observed in the manner in which the predicted O\&G removal correlated with experimental values as shown in Figure 2. The maximum O\&G removal was achieved at lower pollution level (5\%). This result agreed with what was reported by [5].

Optimization findings. It is a well-known fact that optimisation is critical when it comes to decision making concerning processes. The results of the numerical optimization carried out revealed that at $5 \%$ pollution, $75 \mathrm{~g}$ of PBA was capable of achieving $100 \%$ O\&G removal while for $10 \%$ pollution level, $150 \mathrm{~g}$ of PBA was capable of achieving 83.36\% O\&G removal for the ten weeks' remediation period.

Total bacterial count result. Figure 3 illustrates the bacterial growth profile in the treatment cells. It was noticed that the bacterial growth profile followed the batch growth culture of microorganism with lag, exponential, stationary, and death phases. All the treatment cells followed a similar trend of lag phase, the period of 
adaptation to new environment and it lasted for one week. Between weeks two to six, it followed a similar pattern of the exponential phase, the period of maximum used oil consumption. Stationery phase was followed for a period of one week (between weeks six and eight) after which it was followed by death phase which could be due to nutrients exhaustion or secretion toxic substances.

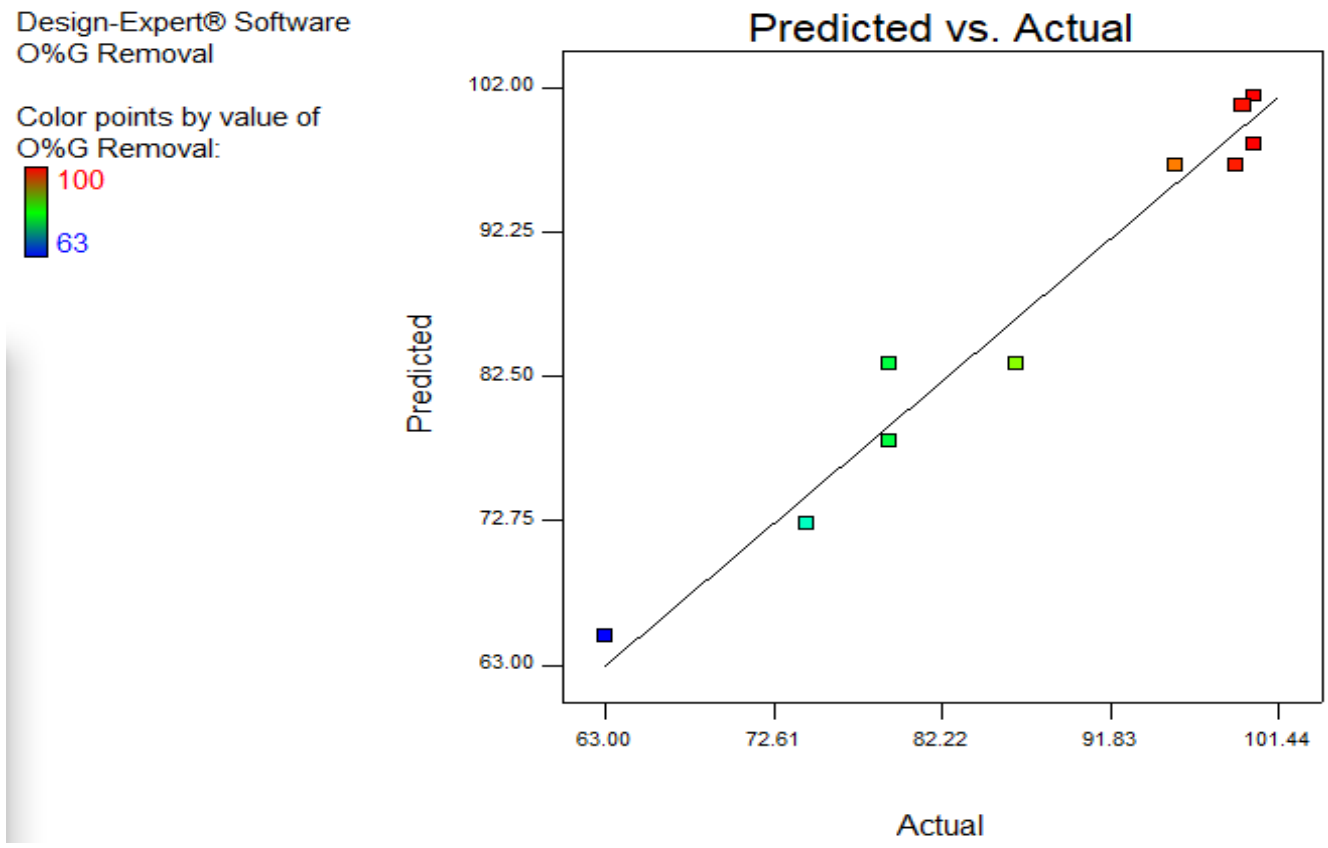

Figure 2 - The predicted and actual (experimental) $0 \& G$ removal

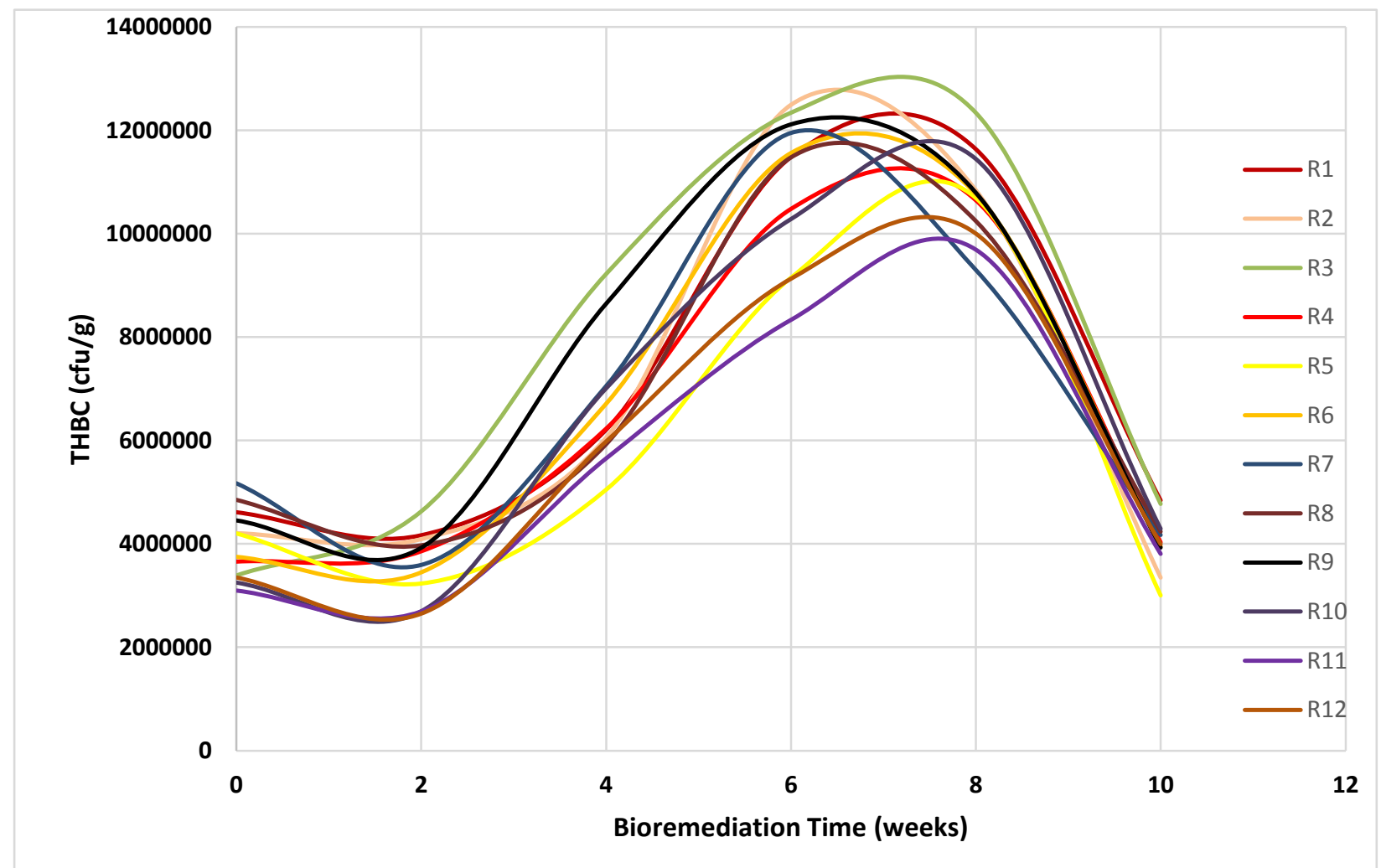

Figure 3 - Variation of total bacterial count with bioremediation time 


\section{CONCLUSION}

This research work has investigated the use of Doptimal RSM design with one categorical factor at two level to find the optimum PBA for the treatment of UMO polluted soil at two different level of pollution. The analysis of variance (ANOVA) revealed the quadratic model best represented the system for $0 \& G$ removal. The results also showed that the O\&G removal was affected by both the PBA and the pollution level. It was also observed from the numerical optimisation carried out that $100 \%$ and $83.36 \%$ O\&G removal could be attained at $5 \%$ and $10 \%$ pollution level respectively after ten weeks of the study.

\section{CONFLICT OF INTEREST}

The authors declared that they have no conflict of interest.

\section{REFERENCES}

1. Abdulsalam, A., Adefia, S., Bugaje, I., \& Ibrahim, S. (2012). Bioremediation of Soil Contaminated With Used Motor Oil in a Closed System. Journal of Bioremediation and Biodegradation, 3(12). doi: 10.4172/2155-6199.1000172

2. Abdulsalam, S., Bugaje, I. M., Adefila, S. S., \& Ibrahim, S. (2010). Comparison of biostimulation and bioaugmentation for remediation of soil contaminated with spent motor oil. International Journal of Environmental Science \& Technology, 8(1), 187-194. doi: 10.1007/bf03326208

3. Abdulyekeen, K. A., Ibrahim, A., Aliyu, A., \& Salis, A. (2018). Kinetic Modelling And Half-Life Study Of The Bioremediation Of Used Motor Oil Contaminated Soil Using Animal Dung As Stimulants. Retrieved from https://www.researchgate.net/publication/327111056_Kinetic_Modelling_and_HalfLife_Study_of_the_Bioremediation_of_Used_Motor_Oil_Contaminated_Soil_using_Animal_Dung_as _Stimulants

4. Abdulyekeen, K. A., Muhammad, I., Giwa, S., \& Abdulsalam, S. (2016). Bioremediation of used motor oil contaminated soil using elephant and horse dung as stimulants. Retrieved from https://www.researchgate.net/publication/311909979_Bioremediation_of_Used_Motor_Oil_Co ntaminated_Soil_Using_Elephant_and_Horse_Dung_as_Stimulants

5. Abioye, O. P., Agamuthu, P., \& Abdul Aziz, A. R. (2012). Biodegradation of Used Motor Oil in Soil Using Organic Waste Amendments. Biotechnology Research International, 2012, 1-8. doi: $10.1155 / 2012 / 587041$

6. Adu, A., Aderinola, O., \& Kusemiju, V. (2015). Comparative effects of spent engine oil and unused engine oil on the growth and yield of vigna unguiculata (cowpea). International Journal of Science and Technology , 4(3), 105-118.

7. Agamuthu, P., Abioye, O. P., \& Aziz, A. A. (2010). Phytoremediation of soil contaminated with used lubricating oil using Jatropha curcas. Journal of Hazardous Materials, 179(1-3), 891-894. doi: 10.1016/j.jhazmat.2010.03.088

8. Agarry SE, \& CN, O. (2012). Enhanced Bioremediation of Soil Artificially Contaminated with Kerosene: Optimization of Biostimulation Agents through Statistical Experimental Design. Journal of Petroleum \& Environmental Biotechnology, 03(03). doi: 10.4172/2157-7463.1000120

9. Agarry, S. E., Owabor, C. N., \& Yusuf, R. O. (2010). Bioremediation of Soil Artificially Contaminated with Petroleum Hydrocarbon Oil Mixtures: Evaluation of the Use of Animal Manure and Chemical Fertilizer. Bioremediation Journal, 14(4), 189-195. doi: 10.1080/10889868.2010.514965

10. Anjana, S., Poonam, K., \& Meenal, B. (2014). Biodegradation of diesel hydrocarbon in soil by bioaugmentation of Pseudomonas aeruginosa: a laboratory scale study. International Journal of Environmental Bioremediation \& Biodegradation, 2(4), 202-212.

11. Chang, R., \& Goldsby, K. (2014). Chemistry: the essential concepts (7th ed.). New York: MCGraw-Hill. 
12. Eremrena, P., \& Mensah, S. (2017). Efficacy of Palm Bunch Ash on the Growth Performance and Mineral Nutrient Composition of Phaseolus vulgaris L. Grown in Diesel Oil Polluted Soil. Journal of Applied Life Sciences International, 10(4), 1-6. doi: 10.9734/jalsi/2017/31310

13. Food and Agriculture Organization of the United Nations. (2008). Guide to laboratory establishment for plant nutrient analysis. Retrieved from http://www.fao.org/3/i0131e/i0131e.pdf

14. Giwa, S., Giwa, A., Zeybek, K., \& Hapoglu, H. (2013). Electrocoagulation Treatment of Petroleum Refinery Wastewater: Optimization through RSM. International Journal of Engineering Research \& Technology, 2(8), 606-614

15. Giwa, S., Abdulyekeen, K. A., Giwa, A., Muhammad, I. (2017). Optimization of Used Motor Oil Contaminated Soil Biostimulation Process. Retrieved from

https://www.researchgate.net/publication/320565522_Optimization_of_Used_Motor_Oil_Conta minated_Soil_Biostimulation_Process

16. Godleads, O., Prekeyi, T., Samson, E., \& Ehinomen, I. (2015). Bioremediation, biostimulation and bioaugmention: a review. International Journal of Environmental Bioremediation \& Biodegradation, 3(1), 28-39.

17. Huang, L., Ma, T., Li, D., Liang, F., Liu, R.-L., \& Li, G. (2008). Optimization of nutrient component for diesel oil degradation by Rhodococcus erythropolis. Marine Pollution Bulletin, 56(10), 17141718. doi: 10.1016/j.marpolbul.2008.07.007

18. Laryea, E. (2013, May). Bioremediation of hydrocarbon contaminated soil using compost, NPK fertilizer and cattle bile as amendment materials (Doctoral thesis), Kwame Nkrumah University of Science and Technology. Retrieved from http://ir.knust.edu.gh/xmlui/bitstream/handle/123456789/5335/FINAL\%20THESIS_\%20201 3.pdf?sequence $=1$

19. Morgan, P., \& Atlas, R. M. (1989). Hydrocarbon Degradation in Soils and Methods for Soil Biotreatment. Critical Reviews in Biotechnology, 8(4), 305-333. doi: 10.3109/07388558909148196

20. Munawar, M., Sasongko, P., \& Kusuma, D. (2014). Optimization of nutrient supplement in hydrocarbon bioremediation process with biostimulation techniques in coastal regions. International Journal of Recent Development in Engineering and Technology, 3(4), 77-83.

21. Obuotor, T., Sakariyau, A., \& Bada, B. (2016). Enhanced Biodegradation of Spent Engine Oil Contaminated Soil using Organic Wastes. Retrieved from https://www.researchgate.net/publication/315316587_Enhanced_Biodegradation_of_Spent_En gine_Oil_Contaminated_Soil_using_Organic_Wastes

22. Ofoegbu, R. U. (2015). Bioremediation of Crude Oil Contaminated Soil Using Organic and Inorganic Fertilizers. Journal of Petroleum \& Environmental Biotechnology, 06(01). doi: 10.4172/21577463.1000198

23. Thapa, B., Kumar, A., \& Ghimire, A. (2012). A Review on Bioremediation Of Petroleum Hydrocarbon Contaminants In Soil. Kathmandu University Journal of Science, Engineering and Technology, 8(1), 164-170. doi: 10.3126/kuset.v8i1.6056

24. Vidali, M. (2001). Bioremediation. An overview. Pure and Applied Chemistry, 73(7), 1163-1172. doi: $10.1351 /$ pac200173071163

25. Walkley, A., \& black, I. A. (1934). An examination of the degtjareff method for determining soil organic matter, and a proposed modification of the chromic acid titration method. Soil Science, 37(1), 29-38. doi: 10.1097/00010694-193401000-00003

26. Zhu, Z., Venosa, A., Suidan, M.., \& Lee, K. (2001). Guidelines for the Bioremediation of Marine Shorelines and Freshwater Wetlands. Retrieved from http://citeseerx.ist.psu.edu/viewdoc/download;jsessionid=16B9F7B72120E788868F74D2396 5AAD9?doi=10.1.1.177.4635\&rep=rep1\&type=pdf 